\title{
Identifying the Role of Technology to Enhance Language Teaching
}

\author{
Reena Mittal
}

\begin{abstract}
These days Language teaching is enhanced by effective uses of educational technology based on research findings in language acquisition and computer-assisted language learning. Best practices take into account effective language pedagogy, and appropriate roles of technology. Best practices in using technology to support language teaching and learning see technology as a tool that can enhance teaching and learning by augmenting input, providing additional opportunities for language practice, and serving as a platform for interaction and tasks-based learning activities. The purpose of this study is to assess the potential of technology for improving language education. A review of the effectiveness of past and current practices in the application of information and communication technology (ICT) in language education and the availability as well as capacities of current ICTs we used. The studies say that existing literature on the effectiveness of technology uses in language education is very limited in four aspects: a) effects of technology uses in language learning is very small, b) the institutions where the studies were conducted were limited c) the languages studied were limited to common foreign languages and English as a foreign or second language, and d) vocabulary or grammar is not taught with the help of ICT. However the limited number of available studies shows a pattern of positive effects. They found technology-supported language learning is at least as effective as human teachers.
\end{abstract}

Index Terms-Language, pedagogy, grammar, Internet, virtual.

\section{INTRODUCTION}

Invent of Computers, Internet, other devices has revolutionized the education system. For the several past decades, we are using these in our teaching. First they have become a part of Pure Sciences, then other subjects and lastly, Humanities and Language has also given a wide scope to technology in Teaching. But it is always a topic of debate about the pedagogical worth of technology in language teaching. On the one hand, Computer and software inventions have opened up many new openings about the usefulness of technology in language teaching. It plays an important role in motivating students too. But the other aspect is sometimes really tantalizing. Students have become so much techno friendly that sometimes they want some or the other miracle to occur as technology has assured them about that miraculous results with the help of using computers through the Internet.

In the field of Language teaching with the help of Computers, I think we have to rethink on specific direction

Manuscript received December 11, 2015; revised August 6, 2016.

Reena Mittal is with the Department of English, DAK Degree College, Moradabad, Uttar Pradesh, 244001 India (e-mail: mittal.reena23@gmail.com). about the use of technology in Language teaching, when we talk about the use of Internet or Computers, we must think that they work till certain extent; on the other hand, language is evolutionary and continuous learning process. [1] People argue that the Internet offer $24 \times 7$ learning environment and it is best for Language learning. But that $24 \times 7$ learning becomes stereotyped to some extent when we talk especially about Grammar, Vocabulary, construction and other things. Language learning offers innovative ideas with altogether new challenges. But Internet repeats the exercises to some or other extent. We, the educators have to rethink and remold our educational system based on technology because it has really some or other constraints which we could not overcome. The present paper is an endeavor to discuss two aspects: One, the use and need of technology in Language learning and secondly, to change present use of ICT into an optimal use of learning. The idea of paper is based on my own teaching experience with or without technology based Language learning.

\section{The BenEFITS OF TeCh LANGUAge LEARNING}

If I see present learning system at a cursory glance, technology is present in our learning all over the world. Even it is there from primary level to higher education. We have Computer labs, and Language labs equipped with multiple devices. Students doing work with the help of Laptops, reading with help of kindle, using Internet and devices for net working with other students and teachers. They learn with help of them, we have apps and devices such as Edmodo, Pronchart, Grammarly and many others which help both teachers and students. Sometimes teachers do two or more tasks simultaneously at same time by using these gadgets. The best use of technology is nothing but CLIL (Content and Language Integrated Learning) [2] they can do projects and topics in innovative way they like, teachers and learners can read as many things through the Internet. We have so many uses of technology supporting language teaching. I was doing a minor project on Second Language learning in schools of my country in 2009. Some astonishing fact came to my knowledge while researching as students who are hesitant in fluent speaking of English, write well while chatting on social media and messaging. They literally enjoy using computers and internet for reading and understanding Poetry. Not only this, some students learn and understand English so well seeing movies that their pronunciation improves so fast beyond my expectation. Even I observed my BA III students understanding the depth of emotions in the poem, "The Night of the Scorpion" with the help of videos and audios. 


\section{Is TEChNOLOGY REALly A SILVER SPOON FOR LANGUAGE LEARNING?}

Teaching and learning now extends beyond four walled classroom. Technological advancement has completely changed learning process. Now, place of old and traditional classroom is converted into anything else. Although technology and its use in language learning has become quite popular now. It was first used in 1960. [3] So, technology is not a new innovation in language teaching. But after 55 years, still this question comes in mind if we are doing justice by using ICT in language classrooms. Another question is, now technology is integral part of teaching but its application and increased use day by day has increased the monotony in the classrooms and teacher-student relationship. In the 20th century, English language teaching methods were developed based on psychological studies of learning methods. Language courses began to integrate approaches that are focused on visual, auditory learning, because students have different learning capacities and use one of their senses more often to acquire information. Teachers began to understand that language acquisition was not a passive process but depended on the learner's interest, habits, background and attitude. My own experience and exposure encourage me to use videos and audios while teaching. I teach to the students whose MT is not English. Many of them come from semi urban background where English is neither spoken nor even taught at school level. In that respect I find these gadgets and gizmos very beneficial. A student, who has never seen Daffodils, can easily understand Wordsworth and his ultimate poem. So, technology really brings revolution in the learning and understanding.

\section{UsE OF TECHNOLOGY IN LANGUAGE TEACHING}

Regarding its use, those who use it regularly in classroom are in its favor. I got opportunity to meet Russell Stannard, a linguistic lecturer at Warwick and founder of a teacher training website, says that technology and language are naturally connected. He opines, Language development is based on four skills-reading, writing, speaking and listening; and all those are facilitated by technology. [4] There is a strong link between them all. It's supported to say that use of technology means using the internet, social networking and other devices for language learning and practices. But when language is learned through language labs purposely designed for learning, it gives a better output than normal classroom activities.

Not only has this but use of videos also revolutionized the teaching. Stannard says that the potential of a video is also incredible as we can present learning and reading more attractive, interesting and practical by use of videos. We cannot only show them (students) videos but we can ask them to make their own videos in which they can practice speaking in their target language.

In all, there is a large group of teachers, substitutions and universities, who, in fact are using technology for language teaching. They are very much satisfied with results. In a special study of 2001, astonishing results came out about the use of technology in Language classes. [5] But Stannard very aptly uses it in his classes by saying that before introducing technology in classroom; what is supposed to be a teacher is to introduce his pedagogy in classroom and then introduce them, why technology is important and compulsory to add in their language classes. Second language learning is always a patient teaching which can only be accomplished with innovative ideas. My students are basically from semi-urban background. English is not in their daily speaking practice, they have to really work hard to grab English as their second language. A language cannot be learned only by a study of Grammar and learning Vocabulary from dictionaries. [6] So, the teachers need to learn innovative teaching ideas and guidance on how technology can best guide and support language learning. I encourage them to see English movies and News Channels which give them exposure to speak and improve their pronunciation.

\section{Classroom Teaching AND VIRTUal Teaching}

There are many practical problems when we talk about the use of technologically equipped classes for language teaching. [7] Some of us may not have equipped classrooms and others have some different problems.

The major ones are:

1) Students remain so much busy in technologically equipped classes using gadgets, that they lack concentration.

2) They talk in their MT, not in target language, whenever they are given any project or presentation to prepare on computers or videos.

3) Face to face learning and teaching puts a different impact on students. Students involve themselves in different experimental use of technology that they deviate from the crux.

4) Use of technology in classroom is to some extent permissible but blended learning is somewhat confusing. Here I mean by blended learning is, teacher and student meet each other online.[8] Although this facility is not there for all my students, still some or other students chat, discuss and meet me online whenever they have some problems. But sometimes that defeat the purpose of teaching. Students pretend as if they are working on given task instead of that they are working on some other.

5) Online learning to some students is not positive learning. To them, face to face teaching, Chalk and duster teaching is really attractive. Technology to them attracts to some extent, but use of all technical devices and app such as Edmodo may not be acceptable.

6) One point here to ponder is there are some websites, language tools and software which give wrong or unsubstantial information. In this regard learner and teacher both feel cheated at some or other points. Technology can play an important role in supporting and enhancing language learning but the effectiveness of any technological tool depends on the knowledge and expertise of the language teacher who manages and facilitates the language learning environment and its authenticity. 


\section{Why TECHNOLOGY LACKS?}

Technology and its use in language teaching have some pros and cons when we discuss them elaborately. [9] A group of people who argue against the use of technology in language teaching have four major points to ponder.

1) Grammar can only be learned with practice, but the student and teachers who argue that they can practice $24 \times 7$ with the help internet are wrong because the kind of exposure they are getting is repetitive not innovative, and language always needs innovative and novel practice ideas.

2) Vocabulary can only be enriched with the use of it. Although technology gives many options for language and vocabulary when we do some or other things electronically. But those options are not always acceptable and also they shut option of using our own brain. Our brain works and reacts with its quick use, but if we use technology all the time, it deactivates our active brain cells.

3) Internet gives us huge exposure when we talk about listening and reading exercises. But always that material provided by net is not useful for a language learner. For speaking and writing, I think the best exercise can only be done when we are face to face with each other. Virtual classrooms or video conferencing cannot be the option for face to face teaching and learning. In classes, students argue with each other which are the best way to add accuracy in speaking and fluency.

4) In present era, Replacement of books is taken by 'Kindle', a device which helps you in reading books. We can download books in it with the help of Internet and read as many times as we want. We can delete once our reading and understanding finishes and download other books. This has made Reading easier, handy and cost friendly. But this has made reading and understanding complex too. We forget it with the passing of time. In books we can make notes, comments and can see and read them as and when required. Kindle also has facility of making footnotes still the difference of feel is there. In Kindle we can restore fixed books which make us to restrict our storage of books. And to inculcate the habit of reading, I still think books are better. E readers don't have a very real feel as reading a book has. Again one more problem is, all this be stressful especially for the eye.

5) One major flaw is the use of CUT, COPY and PASTE. This technique is really a hurdle in the growth of language. Technology has opened up many doors of growth and progress but it sucks when we talk about creative writing. These days students don't use their creative faculty to compose any literary composition. They just surf internet, search related topics and make that according to their need and demand. This has given rise to Plagiarism and nipped the creative writing talent of youngsters.

6) Thinking capability of students and teachers both disappears. They know that they have to give certain commands, click such and such buttons. Teachers guide students to think and cultivate capacity to solve problems but all process is so time consuming that they cannot give and take feedback.

7) Use of technology is good for universities and college where student teacher ratio is 20 or below. But the countries like India and other Asian countries that have larger population and large classrooms, they cannot take technology to be their fair friend.

\section{CAn Technology Replace a Teacher?}

Use of technology seems to be a two-faceted coin, which has advantages on one side and disadvantages on the other.

Really, this sounds worthwhile and interesting as the need of teacher is always very important. Remember, in our country India, the tradition of 'Guru Kul' is very prominent. Even the children of Royal families take their education in Ashrams, under the protection and patronage of 'Gurus' or 'Teachers'. How can we forget the heart touching story of 'Eklavya' who sacrificed his 'Thumb' just to keep his teacher's words. So, when ICT will replace teacher, how can we find such a pure and close knit relationship of a student and a teacher? But when we talk about change in method of teaching, we must not forget that change is the rule of law. So, in this way ICT or Technology is a good, fast and innovative way of Teaching. We the teachers can use it as a 'Bridge' in our classroom teaching. It can break the monotonous way of blackboard teaching, and add new, innovative method of teaching. Always pictorial memory remain in our mind for a longer period, So the use of videos in teaching, learning and working on new languages will always be beneficial. I still remember my class of 2007, which has some speaking problems, as many students came from a community who don't differentiate between the sounds of ' $S$ ' or 'sh'; to them both are ' $\mathrm{S}$ '. I became confused as it totally changed their pronunciation. Their local dialect and accent was so prominent in L2 that they were not accepting all my efforts. Suddenly, an idea struck in my mind, and I showed them some videos of L1 and L2 which I prepared myself by clippings of some movies and some live people. [10] This really works so well and they changed their speaking pattern drastically. At that time even we don't have facility of showing videos to the class, but somehow I managed it with the help of computer lab of my college. No matter how advanced or smart classes we built with the help of computer program or electronic devices, it can never take place of the knowledge and life experience of a teacher. Several researches have been conducted and it has been proven from time to time that teachers bring about the change amongst their students which no technology can. A teacher simply does not impart knowledge or information but he gives essence of his own knowledge and wisdom dipped in his experience of life. Teaching is not about facts and figures only but a teacher leads, guides, facilitates and mentors his students. Teachers are role models for them who set an example and drive them towards for bright future. A good teacher encourages independent thoughts and learning. $\mathrm{He} / \mathrm{she}$ can be a positive influence and inspiration to set and achieve goals. The bond between a teacher and student creates the perfect learning environment; which can never be achieved through virtual learning. Technology can be a helping tool but not a mentor. In this regard, I must admit that 
teaching is a continuous learning process and we have to mold, shape and create the future generations. A creator is always an innovator. Teacher should try to mold himself according to the need of the time. However, it was difficult for traditional English grammar teaching methods to address these concepts until multimedia was integrated.

\section{TECHNOLOGY CAN BE A GOOD FRIEND FOR LANGUAGE TEACHING}

This shows that use of technology can make some reading, writing, listening and understanding more practical, easier and quicker. Its use is easily accessible to all. Virtual classrooms and use of tele conference has reduced all the distances. Now we can fulfil our dream of studying with Worlds best teachers with the help of technology. But the biggest disadvantage, I see is of copying and plagiarisms in the field of writing whether we talk about creative writing or any other. Similarly, the use of electronic devices is making the mind of the students slower and their memory and attention has become short-termed. They can't concentrate much on any particular subject or object. As a result students have become restless and they lack power of concentration. Technology has become an important classroom teaching aid because it can integrate all of the sensory learning methods and address an individual student's needs by requiring total student interaction and response. Because multimedia language programs interest students with visual effects, audio effects and interesting real-life situations, students become enthusiastic and wish to participate more in the language learning process. Students want to learn faster and accurately and they find results in the blending teaching of teacher and technology. All said and done, technology can be a virtuous supporting tool to the English Language teacher and bring life into his teaching lesson plans. The mere use of technology in teaching improves upon the quality of teaching or learning making it focused and easy to grasp.

\section{CONCLUSION}

I must end saying that technology is the need of the hour. It has already entered our homes, work places and in Language teaching too. Let us make it our cup of tea and use it as and when we feel like. We need not make it our oxygen, which give life to all of us; but a supporting system that gives extra energy. Without it we can also live and survive, as teacher-student relationship is the base of language teaching and the success always depend on their cordial relationship. So, let's read, write, study and listen to our teachers/students, use innovative methods to make teaching learning experience interesting and acceptable to all. The quality teaching can be achieved with the help of technology. English language is taking new turns and steps everyday. So, to give best knowledge of English to students', technology should be added in ELT. If we combine the areas where technology can mingle with teaching and financial problems are not there, use of technology is really a gem to add in ELT. Our mind is hay wired to understand technology and devices better in many conditions. Let's use all these apps and devices for enhancement of our language. Thus we must admit that to attain a perfect teaching atmosphere, technological devices are considered as unavoidable element we need in the present hour. In fact, in present teaching situation, we the teachers are highly indebted to technology for making our classroom teaching so innovative and colorful. It has an immense significance in the process of ELT as we are getting better results. In the real sense technological devices have become an unavoidable part of learning and teaching process in this computer and internet age. We cannot deny the fact that our classes and lectures filled with videos are more productive. Finally, it can be assumed that with technological devices we can provide a suitable situation for student enrichment, enhancement and encouragement. So, we the ELT have to equip ourselves with the perfect teaching or learning situation based on technological devices.

\section{REFERENCES}

[1] D. Brinton and W. Gaskill, "Using news broadcast in EFL/ESL classroom," TESOL Quarterly, vol. 12, no. 2, pp. 403-415, 1978.

[2] E. N. Adams, H. W. Morrison, and J. M. Reddy, "Conversation with a computer as a technique of language instruction," $M L J$, vol. 52, pp. 3-16, 1968.

[3] D. M. Bell. (2003). TV news in the EFL/ESL Classroom: Criteria for Selection. TESL-EJ. [Online]. 7(3). pp. 1-17. Available: http://wwwwriting.berkeley.edu/TESL-EJ/ej27/a2.html

[4] H. Decker, "Computer-aided instruction in French syntax," MLJ, vol. 60, pp. 263-273, 1976.

[5] C. Evans, "Using TV news to integrate the four skills: A guide for EFL teachers," 2006.

[6] H. Keller, "Pedagogical wishes for a machine dictionary: An example from Russia," MLJ, vol. 71, pp. 12-17, 1987.

[7] R. M. Cauldwell, "Direct encounters with fast speech on CD Audio to teach listening," System, vol. 24, no. 4, pp. 521-528, 1996.

[8] S. Krashen, Language Acquisition and Language Education, Prentice Hall International, New York, 1981.

[9] S. Silberstein, Techniques and Resources in Teaching Reading, New York: Oxford University Press, 1994.

[10]M. Saville-Troike, "Introducing second language acquisition," New York: Cambridge University Press, 2012.

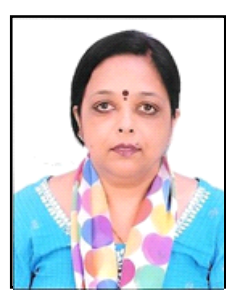

Reena Mittal is an Associate Professor in The D.A.K Degree College, Moradabad, Uttar Pradesh, India. She has been lucky to have 25 papers published in reputed national and international Journals with ISSN. She has attended nearly 35 seminars and workshops actively and enthusiastically while presenting papers in almost all of them. She recently went to The Oxford University, UK for a 15-day summer seminar in English Language Teaching and represented her country, India. It was a lifetime experience learning techniques of English Teaching for her and she plans to bring changes to the current language teaching techniques starting with her college and university. 